\title{
Effect of intermittent deep hypothermic circulatory arrest on brain metabolism
}

The effect of intermittent systemic reperfusion during deep hypothermic circulatory arrest was investigated in dogs to learn how the total arrest period may be prolonged. The animals were cooled on cardiopulmonary bypass to $18^{\circ} \mathrm{C}$ and divided into the following three experimental groups: group I $(n=7), 60$ minutes of uninterrupted circulatory arrest; group II $(n=7), 120$ minutes of circulatory arrest with 10 minutes of intermittent systemic perfusion every 30 minutes during the arrest period; group III $(n=7), 120$ minutes of circulatory arrest with 10 minutes of intermittent systemic perfusion every 20 minutes during the arrest period. Cerebral oxygen extraction rate increased significantly during the arrest periods $(p<0.05)$ and returned to normal after each 10 -minute period of systemic reperfusion in every group. During circulatory arrest, cerebral excess lactate increased in a timedependent manner after 20 minutes $(r=0.78 ; p<0.001)$. Anaerobic metabolism did not increase throughout the circulatory arrest period in group III, although it increased significantly in groups I and II $(p<0.05)$. The present data demonstrate that cerebral energy metabolism becomes predominantly anaerobic within the first $\mathbf{2 0}$ minutes of deep hypothermic circulatory arrest. The present findings suggest that intermittent systemic recirculation for brief 10-minute periods every 20 minutes during circulatory arrest should prevent cerebral anaerobic metabolism during long periods of arrest that are required to complete complicated surgical repairs. (J THORAC CARDIOVASC SURG 1994;108:658-63)

Tetsuya Kimura, MD, Ryusuke Muraoka, MD, Yukio Chiba, MD, Akio Ihaya, MD, and Koichi Morioka, MD, Fukui, Japan

$D_{\text {ee }}$ eep hypothermic circulatory arrest is used to enhance surgical repair not only of complex congenital cardiac anomalies in infants ${ }^{1,2}$ but also of thoracic aortic arch aneurysms in adults. ${ }^{3,4}$ Despite the protective effect of hypothermia, the risk of neurologic injury has been a major limitation of the duration of circulatory arrest. The generally accepted safe duration of circulatory arrest has been estimated to be 45 to 60 minutes. ${ }^{5-9}$ However, experimental studies have shown cellular damage in animals ${ }^{10}$ and human beings ${ }^{11}$ subjected to cold ischemic times similar to those used clinically.

Some options are available to avoid ischemic damage during circulatory arrest: (1) continuous low-flow sys-

From The Second Department of Surgery, Fukui Medical School, Matsuoka, Fukui 910-11, Japan.

Received for publication Nov. 19, 1993.

Accepted for publication April 7, 1994.

Address for reprints: Tetsuya Kimura, MD, The Second Department of Surgery, Fukui Medical School, 23 Shimoaizuki Matsuoka-cho, Yoshida-gun Fukui-ken 910-11, Japan.

Copyright ${ }^{\circledR} 1994$ by Mosby-Year Book, Inc.

$0022-5223 / 94 \$ 3.00+0 \quad \mathbf{1 2} / \mathbf{1} / \mathbf{5 6 6 9 7}$ temic perfusion during the repair, (2) additional circulatory arrest followed by systemic reperfusion, or (3) extension of the arrest period with the use of cerebroplegic agents or cooling to a lower temperature. On the basis of these options, various techniques have been attempted to minimize cellular damage. ${ }^{12-15}$

A few investigations of intermittent reperfusion during periods of deep hypothermic circulatory arrest have been conducted. ${ }^{16}$ The purpose of the present study is to evaluate how hypothermic intermittent systemic perfusion may be used to prolong the total arrest period.

\section{Material and methods}

Animal preparation. Every animal received humane care in compliance with the "Principles of Laboratory Animal Care" formulated by the National Society for Medical Research and the "Guide for the Care and Use of Laboratory Animals" prepared by the National Academy of Sciences and published by the National Institutes of Health (NIH Publication No. 85-23, revised 1985).

Twenty-one adult mongrel dogs weighing 7.5 to $12 \mathrm{~kg}$ were used in the present experiments. The animals were allowed free access to food and water in a ventilated room with a 12-hour light-dark cycle up to the time of the experiment. Animals were 
anesthetized with ketamine hydrochloride $(10 \mathrm{mg} / \mathrm{kg}$ intramuscularly) and pentobarbital sodium $(2.5 \mathrm{mg} / \mathrm{kg}$ intravenously) and paralyzed with pancuronium bromide $(0.2 \mathrm{mg} / \mathrm{kg}$ intravenously). Positive-pressure mechanical ventilation (Harvard Apparatus Co., Inc., S. Natick, Mass.) was maintained with a mixture of $40 \%$ oxygen, $60 \%$ nitrous oxide, and $0.5 \%$ to $1.0 \%$ enflurane. Standard lead II was used for electrocardiographic recordings. Nasopharyngeal and rectal temperature probes were placed, and a 22-gauge left carotid artery catheter was inserted for continuous blood pressure monitoring and arterial blood sampling. Sagittal sinus cannulation was performed through the midline sagittal suture for cerebral blood sampling.

Cardiopulmonary bypass technique. The cardiopulmonary bypass (CPB) circuit consisted of a Stökert-Shiley CAPS nonpulsatile roller pump (Shiley, Inc., Irvine, Calif.), a Harvey bubble oxygenator (H-400, C.R. Bard, Inc., Santa Ana, Calif.), and a $40 \mu \mathrm{m}$ arterial filter (AF-540, Bentley Laboratories, Inc., Irvine, Calif.). The oxygenator was primed with homologous fresh blood $(800 \mathrm{ml})$, lactated Ringer's solution $(400 \mathrm{ml}), 20 \%$ mannitol solution $(60 \mathrm{ml})$, and $8.4 \%$ sodium bicarbonate $(80$ $\mathrm{ml}$ ), to which $2000 \mathrm{IU}$ of heparin and $5 \mathrm{ml}$ of calcium gluconate were added. After median sternotomy and systemic heparinization $(300 \mathrm{IU} / \mathrm{kg})$, a $28 \mathrm{~F}$ two-stage venous cannula was placed in the inferior vena cava through the right atrial appendage and a $14 \mathrm{~F}$ arterial cannula was placed in the right femoral artery. The oxygenator was ventilated with oxygen and $2 \%$ carbon dioxide at a ventilation/perfusion ratio of 1.0. Arterial oxygen tension was maintained at greater than $100 \mathrm{~mm} \mathrm{Hg}$ and carbon dioxide tension was kept between 35 and $45 \mathrm{~mm} \mathrm{Hg}$ by means of the alpha-stat scheme. Core cooling was initiated with a CPB flow of 100 to $120 \mathrm{ml} / \mathrm{kg}$ per minute and adjusted to 80 $\mathrm{ml} / \mathrm{kg}$ per minute when the temperature was below $20^{\circ} \mathrm{C}$. The aortic root was crossclamped at $28^{\circ} \mathrm{C}$ to eliminate the influence of the left ventricle. Nasopharyngeal and rectal temperatures were maintained at $17^{\circ} \pm 1^{\circ} \mathrm{C}$.

Experimental protocol and data collection. The animals were divided into three groups: animals in group I $(n=7)$ underwent a single 60-minute period of circulatory arrest; in group II ( $n=7)$ animals underwent 120 minutes of circulatory arrest with 10 minutes of intermittent systemic perfusion (80 $\mathrm{ml} / \mathrm{kg}$ per minute) every 30 minutes; and group III animals $(n=7)$ also had 120 minutes of circulatory arrest with 10 minutes of intermittent systemic perfusion $(80 \mathrm{ml} / \mathrm{kg}$ per minute) every 20 minutes.

Blood samples for gas analysis were obtained from arterial and venous lines of the $\mathrm{CPB}$ circuit and from the sagittal sinus. Oxygen tension $\left(\mathrm{PO}_{2}\right)$, carbon dioxide tension $\left(\mathrm{PCO}_{2}\right)$, and $\mathrm{pH}$ were measured with a Ciba Corning $178 \mathrm{pH} /$ blood gas analyzer (Ciba Corning Diagnostics Corp., Medfield, Mass). Oxygen content $\left(\mathrm{CO}_{2}\right)$ and cerebral oxygen extraction rate (OER) were calculated by standard formulas ${ }^{17}$ :

$$
\begin{gathered}
\mathrm{CO}_{2}(\text { vol } \%)=\left(1.34 \cdot \mathrm{Hb} \cdot \% \mathrm{O}_{2} \text { sat. }\right) / 100+0.003 \cdot \mathrm{Po}_{2} \\
\text { OER }=\left(\mathrm{CaO}_{2}-\mathrm{CvO}_{2}\right) / \mathrm{CaO}_{2}
\end{gathered}
$$

where $\mathrm{Hb}$ is hemoglobin, $\mathrm{O}_{2}$ sat. is oxygen saturation, $\mathrm{CaO}_{2}$ is arterial oxygen content, and $\mathrm{CvO}_{2}$ is sagittal sinus blood oxygen content.

So that lactate and pyruvate concentrations could be determined, arterial and sagittal blood samples $(1 \mathrm{ml})$ were collected during each systemic reperfusion period at $0.5,2,3,5$, and 10 minutes. At 30 minutes after the final arrest, the last set of
Table I. Selected parameters at normothermia and

\begin{tabular}{|c|c|c|}
\hline & Normothermia & Hypothermia \\
\hline MAP $(\mathrm{mm} \mathrm{Hg})$ & $83.6 \pm 3.8$ & $53.5 \pm 2.8^{\dagger}$ \\
\hline $\mathrm{pH}$ & $7.476 \pm 0.014$ & $7.479 \pm 0.034$ \\
\hline $\mathrm{Po}_{2}(\mathrm{~mm} \mathrm{Hg})$ & $189.9 \pm 30.1$ & $494.5 \pm 23.0 \dagger$ \\
\hline $\mathrm{PCO}_{2}(\mathrm{~mm} \mathrm{Hg})$ & $26.8 \pm 2.0$ & $29.8 \pm 2.1$ \\
\hline $\mathrm{O}_{2}$ sat $(\%)$ & $99.1 \pm 0.2$ & $99.9 \pm 0.1 \dagger$ \\
\hline Hematocrit (\%) & $40.2 \pm 2.6$ & $21.9 \pm 1.4^{\dagger}$ \\
\hline $\begin{array}{l}\text { Cerebral } \mathrm{O}_{2} \text { difference* } \\
\quad(\mathrm{ml} / \mathrm{dl})\end{array}$ & $7.10 \pm 0.71$ & $1.31 \pm 0.21 \dagger$ \\
\hline Cerebral OER (\%) & $33.7 \pm 3.0$ & $12.1 \pm 2.3 \dagger$ \\
\hline
\end{tabular}
hypothermia for all animals $(\mathrm{n}=21)$

$n$, Number of animals; $M A P$, mean arterial pressure; $\mathrm{PO}_{2}$, oxygen tension; $\mathrm{PCO}_{2}$ carbon dioxide tension; $\mathrm{O}_{2}$ sat, oxygen saturation; $O E R$, oxygen extraction rate.

*Arterioságittal oxygen content.

$\dagger p<0.05$ versus normothermic values.

measurements was taken. Lactate and pyruvate were measured enzymatically as described. ${ }^{18}$ To estimate the extent and duration of anaerobic metabolism, we calculated lactate extraction and cerebral excess lactate $(\Delta X L)$ as follows ${ }^{19}$ :

$$
\begin{gathered}
\text { Lactate extraction }=\mathrm{Lv}-\mathrm{La} \\
\Delta \mathrm{XL}(\mathrm{mmol} / \mathrm{L})=(\mathrm{Lv}-\mathrm{La})-(\mathrm{Pv}-\mathrm{Pa}) \cdot(\mathrm{La} / \mathrm{Pa})
\end{gathered}
$$

where $\mathrm{La}$ and $\mathrm{Pa}$ are arterial blood concentrations of lactate and pyruvate, respectively, and Lv and Pv are the simultaneously measured concentrations in sagittal blood.

Analysis. Each value is expressed as the mean \pm standard error of the mean. Statistical evaluation was performed by means of Student's unpaired $t$ test for comparison of experimental variables between the groups, and the paired Student's $t$ test was used to compare paired data obtained in each animal. Significance was assumed at a $p$ value less than 0.05 .

\section{Results}

General effects of hypothermia. Normothermic and hypothermic values for all animals are listed in Table I. As compared with values during normothermia, perfusion cooling at $18^{\circ} \mathrm{C}$ caused significant reductions in mean arterial pressure, cerebral arterial-sagittal venous oxygen difference, and oxygen extraction rate $(p<0.05)$.

Cerebral oxygen extraction rate. The changes in oxygen extraction rate are shown in Table I and Fig. 1. As compared with values during normothermia, oxygen extraction rate at $18^{\circ} \mathrm{C}$ was reduced markedly by $46.7 \% \pm 1.7 \%$. No significant difference between groups was observed at any individual time point. In every group, the oxygen extraction rate increased significantly after each period of ischemia and returned to the control value within 10 minutes of reperfusion.

Cerebral excess lactate. The changes in cerebral excess lactate content are shown in Table II and Figs. 2 and 3. The peak cerebral excess lactate concentration was reached within the first 30 seconds after reperfusion, and subsequently this release returned rapidly to the preis- 
Group I

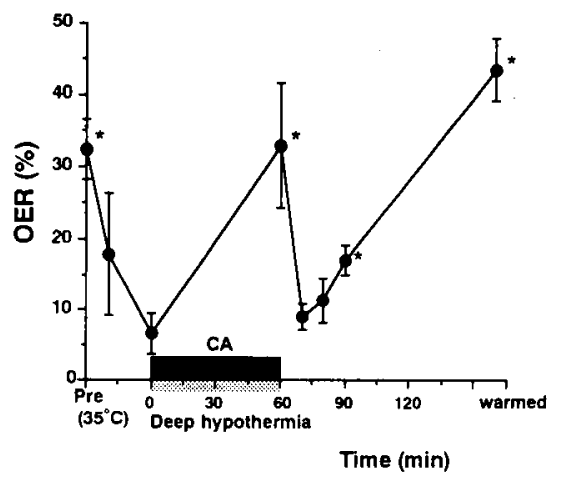

Group II

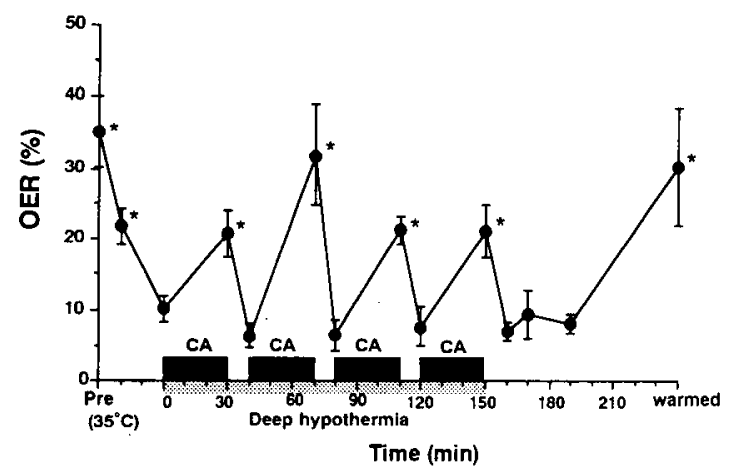

Group III

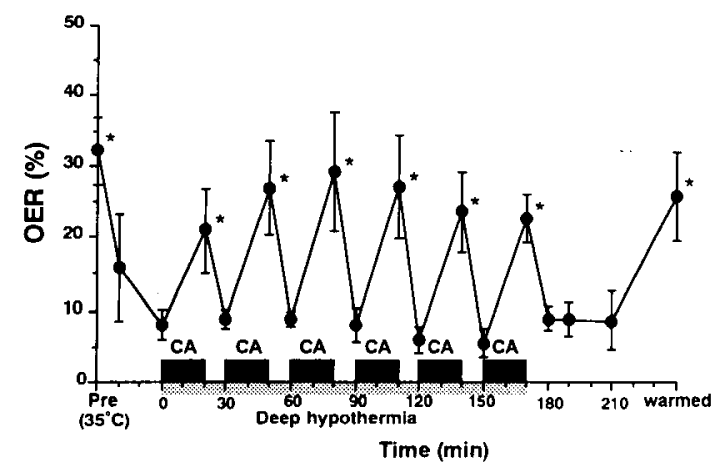

Fig. 1. Cerebral oxygen extraction rate $(O E R)$ during the experiments. $C A$, Circulatory arrest. Data are presented as mean \pm standard deviation of the mean. ${ }^{*}$ Significantly different from the preischemic value at $18^{\circ} \mathrm{C}(p<0.05)$. No significant differences among the three groups were observed.

chemic level (Fig. 2). In general the peak cerebral excess lactate content did not differ significantly within a group. A correlation existed between the duration of circulatory arrest and cerebral excess lactate content (Fig. 3). Regression analysis of the relationship predicts that at $18^{\circ} \mathrm{C}$, cerebral excess lactate $(\mathrm{mmol} / \mathrm{L})=(0.0744$. Arrest duration - 1.17); $(r=0.78, p<0.001)$.

No significant difference was observed among animals
Group 1
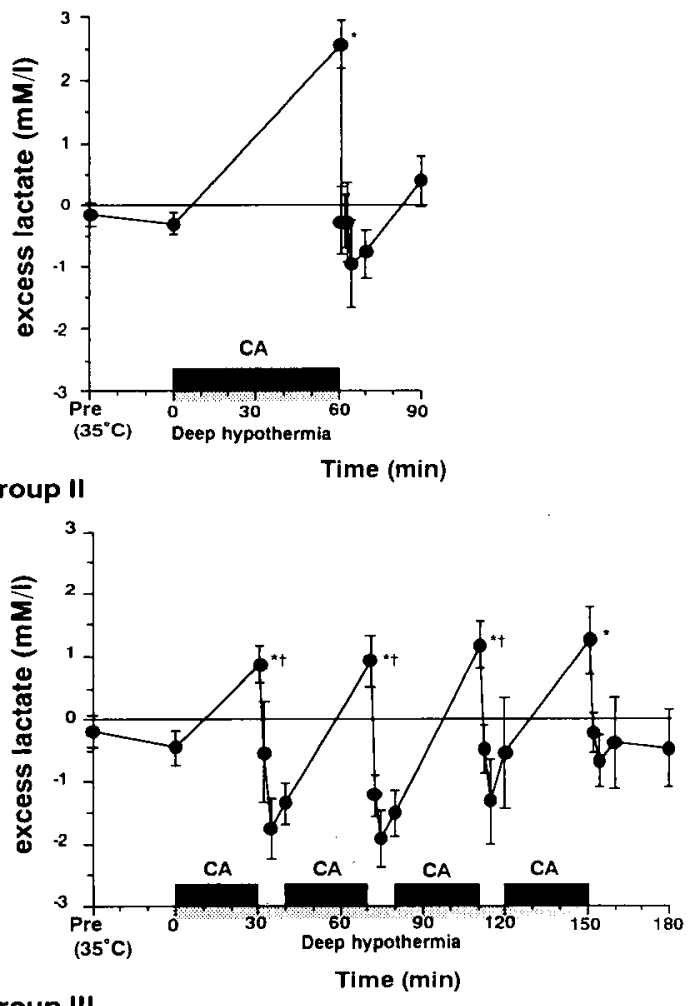

Group III

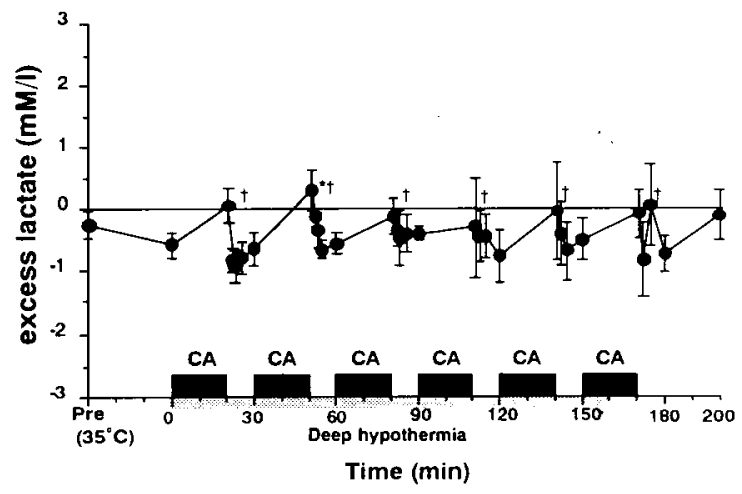

Fig. 2. Cerebral excess lactate during the experiments. $C A$, Circulatory arrest. Data are presented as mean \pm standard error of the mean $(\mathrm{mmol} / \mathrm{L})$. *Significantly different from the preischemic value at $18^{\circ} \mathrm{C}(p<0.05){ }^{\dagger}$ Significantly different from group I $(p<0.05)$.

in the three groups in terms of temperature, mean arterial pressure, arterial $\mathrm{pH}$, blood gases, or hematocrit value at any time point.

\section{Discussion}

Relative to other organs, the brain's metabolic requirement for oxygen is high and its tolerance to ischemia is low. The use of deep hypothermia reduces metabolic 


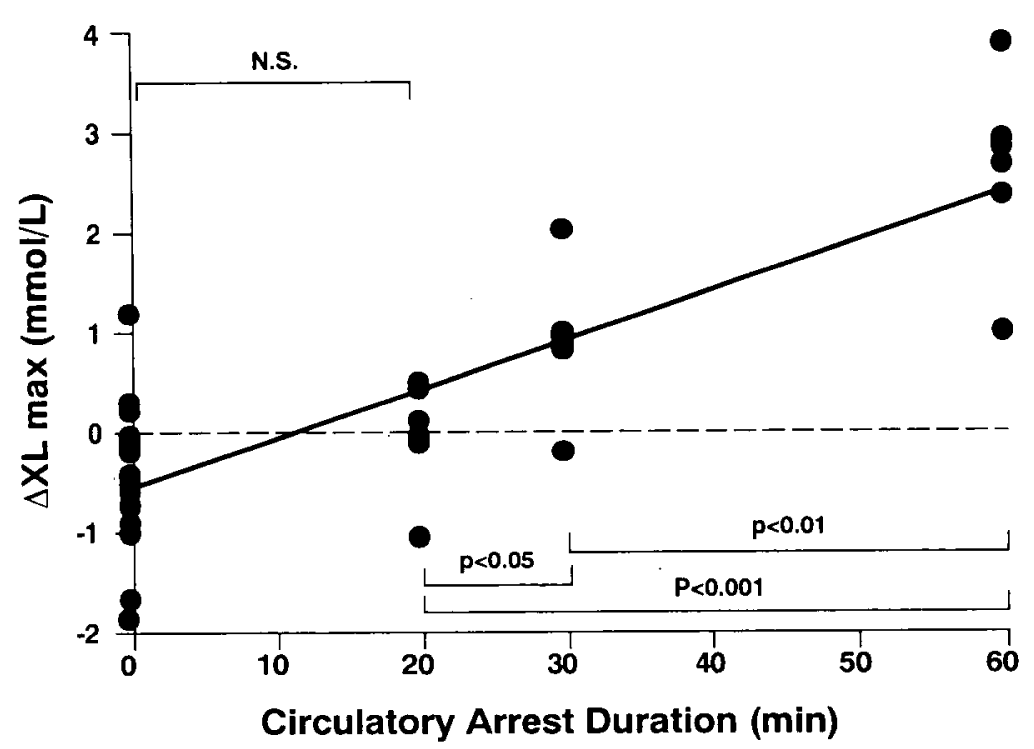

Fig. 3. Relationship between cerebral excess lactate $(\triangle X L)$ content and the duration of circulatory arrest $(C A)$. Least-squares regression of cerebral excess lactate versus duration of circulatory arrest demonstrated a linear relationship with $r^{2}=0.76(p=0.001)$. This relationship is predicted by the formula: $\Delta \mathrm{XL}=(0.0744$. CA duration - 1.17). NS, Not significant.

Table II. Arterial concentrations of lactate and pyruvate, lactate extraction rate, and excess lactate production

\begin{tabular}{lcccc}
\hline & & \multicolumn{3}{c}{ Duration of CA } \\
\cline { 3 - 5 } & & $\begin{array}{l}20 \min \\
(\mathrm{n}=6)\end{array}$ & $\begin{array}{c}30 \text { min } \\
(\mathrm{n}=6)\end{array}$ & $\begin{array}{c}60 \min \\
(\mathrm{n}=6)\end{array}$ \\
\hline Lactate $(\mathrm{mg} / \mathrm{dl})$ & $80.6 \pm 4.2$ & $71.0 \pm 5.9$ & $84.7 \pm 7.0$ & $78.0 \pm 2.1$ \\
Pyruvate $(\mathrm{mg} / \mathrm{dl})$ & $7.80 \pm 0.12$ & $1.53 \pm 0.19$ & $1.76 \pm 0.26$ & $2.16 \pm 0.28$ \\
Lactate extraction & $-1.85 \pm 2.14$ & $-1.42 \pm 1.95$ & $8.73 \pm 5.30$ & $0.13 \pm 3.11$ \\
Excess lactate $(\mathrm{mmol} / \mathrm{L})$ & $-0.420 \pm 0.187$ & $-0.058 \pm 0.227$ & $0.877 \pm 0.287^{*} \dagger$ & $2.570 \pm 0.381^{*}+\ddagger$ \\
\hline
\end{tabular}

$C A$, Circulatory arrest; $n$, number of animals; Data are presented as mean \pm standard error of the mean.

${ }^{*} p<0.05$ versus pre-CA

$\dagger p<0.05$ versus 20 minutes.

$\ddagger p<0.05$ versus 30 minutes.

activity and thereby provides a degree of cerebral protection. Oxygen consumption is decreased by approximately $5 \%$ per degree Celsius between $37^{\circ}$ and $22^{\circ} \mathrm{C},{ }^{20}$ and at $20^{\circ} \mathrm{C}$ it is one fifth that during normothermia. ${ }^{21,22}$ These findings are similar to the oxygen extraction rate obtained in this study. Despite the reduction of oxygen demand, metabolic processes operate even below $20^{\circ} \mathrm{C}$. After each period of reperfusion, the oxygen extraction rate returned to the preischemic level in each group, which indicates that a 10-minute reperfusion period is sufficient for recovery of the extracellular environment of the hypoxic cell.

Information regarding anaerobic metabolism during deep hypothermic arrest has been difficult to obtain. Lactate, the final product of anaerobic glycolysis, is insufficient when considered alone for assessing anaerobic metabolism because its concentration rises with hyperventilation, alkalosis, or use of glucose or lactated Ringer's solution for CPB priming. Cerebral excess lactate has been shown to develop as a result of anaerobic metabolism without significant influence by any other factor. ${ }^{19}$ The brain has no oxygen reserve, and, when oxygen is lacking, high-energy phosphates are depleted and anaerobic metabolism predominates. This study defined a linear relationship between the duration of circulatory arrest and excess lactate production. During deep hypothermia in the dog, cerebral anaerobic metabolism became progressively worse after a 20 -minute arrest period. This suggests that the hypothermic brain exhausts most of its free energy stores within 20 minutes of circulatory arrest 
at $18^{\circ} \mathrm{C}$. Then anaerobic glycolysis develops, resulting in adenosine triphosphate synthesis and lactate production. Other investigators ${ }^{23,}{ }^{24}$ have shown that cerebral cortical tissue oxygen is depleted rapidly during the initial 15 to 20 minutes of deep hypothermic circulatory arrest, and the subsequent elevation of cortical carbon dioxide tension is interpreted as being a result of anaerobic metabolism. Anderson and associates ${ }^{25}$ reported that, in hyperglycemic sheep, cerebral $\mathrm{pH}$ becomes more acidotic than in normoglycemic animals after the first 30 minutes of hypothermic circulatory arrest because of anaerobic glycolysis. These findings, like our own findings, suggest that the alteration of cerebral energy metabolism occurs early during circulatory arrest.

Although the safe duration of circulatory arrest has been estimated to be 45 to 60 minutes, ${ }^{5-9}$ the marked development of cerebral excess lactate during 60 minutes of arrest offers the possibility of minimal cerebral injury. Muraoka and associates ${ }^{11}$ documented cellular damage in children subjected to a period of cold ischemia lasting as long as those used clinically.

In some difficult cases, when a long circulatory arrest time is anticipated, additional periods of circulatory arrests after periodic systemic reperfusion are often required. However, little quantitative information regarding repetitive systemic perfusion and its effects on the brain is available. In the present study, anaerobic cerebral excess lactate production was not observed throughout intermittent circulatory arrest with 20-minute arrest periods in group III, but it was not prevented with 30-minute arrest periods in group II. This observation suggests that intermittent long periods of circulatory arrest risk cerebral damage. Swain and associates ${ }^{13}$ performed intermittent 1 -hour periods of circulatory arrest with 30 minutes of systemic reperfusion in sheep at $15^{\circ} \mathrm{C}$ and observed postischemic intracellular acidosis with incomplete repletion of high-energy phosphate concentrations.

Recently, it was shown that repetitive short periods of cerebral ischemia at normothermia result in "delayed neuronal damage."26, 27 However, the influence of repetitive cerebral ischemia at hypothermia is unknown. It is thought that neuronal damage occurs when oxygenated blood is recirculated frequently to an anaerobic area. Interestingly, in the present study, a rapid decrease in cerebral excess lactate production was observed during the long periods of arrest in groups I and II. A satisfactory explanation for this finding cannot be offered and further examination is warranted.

In summary, cerebral energy metabolism becomes anaerobic after the first 20 minutes of deep hypothermic circulatory arrest. Intermittent circulatory arrest of short duration, less than 20 minutes, will be useful for preventing cerebral anaerobic metabolism when longer periods of arrest are needed to complete complicated surgical repairs.

\section{R EFERE N C ES}

1. Castaneda AR, Lamberti J, Sand RM, Williams RG, Nadas AS. Open heart surgery during the first 3 months of life. J Thorac Cardiovasc Surg 1974;68:719-31.

2. Hikasa $Y$, Shirotani H, Satomura K, et al. Open heart surgery in infants with an aid of hypothermic anesthesia. Arch Jpn Chir 1967;36:495-508.

3. Crawford ES, Coselli JS, Safi HJ. Partial cardiopulmonary bypass, hypothermic circulatory arrest, and posterolateral exposure for thoracic aortic aneurysm operation. J THORAC Cardiovasc Surg 1987;94:824-7.

4. Ergin MA, O'Connor JV, Guinto R, Griepp RB. Experience with profound hypothermia and circulatory arrest in the treatment of aneurysms of the aortic arch. J THORAC CARDIOVASC SURG 1982;84:649-55.

5. Treasure T, Naftel DC, Conger KA, Garcia JH, Kirklin JW, Blackstone EH. The effect of hypothermic circulatory arrest time on cerebral function, morphology, and biochemistry. J THORAC CARdiovasc SURG 1983;86:761-70.

6. O'Connor JV, Wilding T, Farmer P, Sher J, Ergin MA, Griepp R B. The protective effect of profound hypothermia on the canine central nervous system during one hour of circulatory arrest. Ann Thorac Surg 1986;41:255-9.

7. Mohri H, Barnes RW, Winterscheid LC, Dillard DH, Merendino KA. Challenge of prolonged suspended animation: a method of surface induced deep hypothermia. Ann Surg 1968;168:779-87.

8. Kramer RS, Sanders AP, Lesage AM, Woodhall B, Sealy WC. The effect of profound hypothermia on preservation of cerebral ATP content during circulatory arrest. J THOrac Cardiovasc Surg 1968;56:699-709.

9. Wells FC, Coghill S, Caplan HL, Lincoln C, Kirklin JW. Duration of circulatory arrest does influence the psychological development of children after cardiac operation in early life. J THORAC CARDIOvASC SURG 1983;86:823-31

10. Molina JE, Einzig S, Mastri AR, et al. Brain damage in profound hypothermia: perfusion versus circulatory arrest. J Thorac CARdiovasc Surg 1984;87:596-604.

11. Muraoka R, Yokota M, Aoshima M, et al. Subclinical changes in brain morphology following cardiac operations as reflected by computed tomographic scans of the brain. $J$ Thorac Cardiovasc Surg 1981;81:364-9.

12. Miyamoto K, Kawashima Y, Matsuda H, Okuda A, Maeda S, Hirose H. Optimal perfusion flow rate for the brain during deep hypothermic cardiopulmonary bypass at $20^{\circ}$ C. J Thorac CardiovasC Surg 1986;92:1065-70.

13. Swain JA, McDonald TJ, Griffith PK, Balaban RS, Clark $\mathrm{RE}$, Ceckler T. Low-flow hypothermic cardiopulmonary bypass protects the brain. J THORAC CARDIOVASC SURG 1991;102:76-84.

14. Asano K, Sakurai Y, Irisawa T, Aoki E, Amano K. Sep- 
arate cardiopulmonary bypass as an aid of surgery of thoracic aortic aneurysms. Jpn J Thorac Surg 1970;23:77-82.

15. Bloodwell RD, Hallman GL, Cooley DA. Aneurysm of the ascending aorta with aortic valvular insufficiency: surgery management. Arch Surg 1966;92:588-99.

16. Robbins RC, Balaban RS, Swain JA. Intermittent hypothermic asanguineous cerebral perfusion (cerebroplegia) protects the brain during prolonged circulatory arrest. J THORAC CARDIOvaSC SURG 1990;99:878-84.

17. Croughwell N, Smith LR, Quill T, et al. The effect of temperature on cerebral metabolism and blood flow in adults during cardiopulmonary bypass. J THORAC CARDIOvASC SuRG 1992;103:549-54.

18. Van der Vusse GJ, Van Belle H, Van Gerven W, Kruger $\mathrm{R}$, Reneman RS. Acute effect of fentanyl on hemodynamics and myocardial carbohydrate utilization and phosphate release during ischemia. Br J Anaesth 1979;51:927-35.

19. Hukabee WE. Relationship of pyruvate and lactate during anaerobic metabolism. IV. Local tissue components of total body $\mathrm{O}_{2}$-debt. Am J Physiol 1959;196:253-60.

20. Michenfelder JD, Milde $\mathrm{JH}$. The effect of profound levels of hypothermia (below $14^{\circ} \mathrm{C}$ ) on canine cerebral metabolism. J Cereb Blood Flow Metab 1992;12:877-80.

21. Fox LS, Blackstone EH, Kirklin JW, Bishop SP, Bergdahl LAL, Bradley EL. Relationship of brain blood flow and oxygen consumption to perfusion flow rate during profoundly hypothermic cardiopulmonary bypass. J THORAC CARDIOVASC SURG 1984;87:658-64.

22. Norwood WI, Norwood C, Ingwall JS, Castaneda AR, Fosssel ET. Hypothermic circulatory arrest: phosphorus 31 nuclear magnetic resonance of isolated perfused neonatal rat brain. J Thorac Cardiovasc SuRg 1979;78:823-30.

23. Perna AM, Gardner TJ, Tabaddor K, Brawley RK, Gott VL. Cerebral metabolism and blood flow after circulatory arrest during deep hypothermia. Ann Surg 1973;178:95101 .

24. Watanabe T, Miura M, Orita H, Kobayasi M, Washio $\mathrm{M}$. Brain tissue $\mathrm{pH}$, oxygen tension, and carbon dioxide tension in profoundly hypothermic cardiopulmonary bypass. $\mathbf{J}$ Thorac Cardiovasc Surg 1990;100:274-80.

25. Anderson RV, Siegman M, Balaban RS, Ceckler TL, Swain JA. Hyperglycemia increases cerebral intracellular acidosis during circulatory arrest. Ann Thorac Surg 1992; 54:1126-30.

26. Shuaib A, Ijaz S, Kalra J, Code W. Repetitive transient forebrain ischemia in gerbils: delayed neuronal damage in the substantia nigra reticulata. Brain Res 1992;574:120-4.

27. Nakano S, Kato H, Kogure K. Neuronal damage in the rat hippocampus in a new model of repeated reversible transient cerebral ischemia. Brain Res 1989;490:178-80. 